\title{
DRINKING UNDER CONTROL PROGRAMMES: PERCEPTION OF ALCOHOL-RELATED HARM REDUCTION MEASURES in Poland. Results of a qualitative study AMONG OUTPATIENT ALCOHOL TREATMENT PROVIDERS
} PERCEPCJA PROGRAMÓW REDUKCJI SZKÓD SKIEROWANYCH DO OSÓB UZALEŻNIONYCH OD ALKOHOLU. WYNIKI BADANIA JAKOŚCIOWEGO WŚRÓD TERAPEUTÓW ALKOHOLOWEGO LECZNICTWA AMBULATORYJnego $\mathbf{W}$ POLsce

\author{
Justyna I. Klingemann ${ }^{1}$, Harald Klingemann ${ }^{2}$ \\ ${ }^{1}$ Institute of Psychiatry and Neurology, Department of Studies on Alcoholism and Drug Dependence, Warsaw, Poland \\ ${ }^{1}$ Instytut Psychiatrii i Neurologii, Zakład Badań nad Alkoholizmem i Toksykomaniami, Warszawa, Polska \\ ${ }^{2}$ University of Applied Sciences, Bern, Switzerland
}

Alcohol Drug Addict 2017; 30 (3): 161-170 DOI: https://doi.org/10.5114/ain.2017.72310

\begin{abstract}
Introduction: Harm reduction programmes for drug addicts are well documented and accepted by practitioners, whereas harm reduction programmes for alcohol addicts are under researched and encounter resistance. The article presents the results of a qualitative study focused on the perception of two case studies of drinking under control programmes (DUCPs) by outpatient treatment providers working in abstinence-focused Polish alcohol treatment system.
\end{abstract}

\begin{abstract}
Streszczenie
Wprowadzenie: Programy redukcji szkód skierowane do osób uzależnionych od narkotyków są dobrze udokumentowane i akceptowane przez środowisko terapeutyczne. Jednocześnie programy tego typu skierowane do osób uzależnionych od alkoholu są rzadko tematem opracowań naukowych, a ich realizacja napotyka opór środowiska. Artykuł prezentuje wyniki badania jakościowego poświęconego percepcji dwóch przykładowych programów redukcji szkód dla osób uzależnionych od alkoholu, zrealizowanego z terapeutami uzależnienia od alkoholu.
\end{abstract}

Correspondence to/Adres do korespondencji: Justyna Klingemann, Zakład Badań nad Alkoholizmem i Toksykomaniami, Instytut Psychiatrii i Neurologii, ul. Sobieskiego 9, 02-957 Warszawa, Polska, phone: +48 22458 27 79, e-mail: zulewska@ipin.edu.pl

Authors' contribution/Wkład pracy autorów: Study design/Koncepcja badania: J. Klingemann / Data collection/Zebranie danych: J. Klingemann / Data interpretation/Interpretacja danych: J. Klingemann, H. Klingemann / Acceptance of final manuscript version/ Akceptacja ostatecznej wersji: J. Klingemann, H. Klingemann / Literature Search/Przygotowanie literatury: J. Klingemann, H. Klingemann / Funds collection/Pozyskanie środków (finansowania): J. Klingemann

No ghostwriting and guest authorship declared./Nie występują zjawiska ghostwriting i guest authorship.

Submitted/Otrzymano: 12.10.2017• Accepted/Przyjęto do druku: 30.11.2017 
Material and methods: The 26 alcohol addiction professionals were participants of four focus group interviews (FGI), which were audio-recorded and transcribed verbatim. Data were coded and analysed using ATLAS.ti software (version 7.5.9).

Results: Three types of barriers were identified: (1) prevailing orientation towards abstinence and related images of addiction; (2) difficulties to match client profiles with the DUCPs characteristics; (3) cultural norms related to historical features and collective memories in Poland as a post-communist country.

Discussion: The provision of alcohol as breaking a taboo remained the centre of critique, even when linked with work as an important societal value, and regardless of the harm reduction perspective and outcomes of DUCPs, to which there was only marginal reference.

Conclusions: Treatment counsellors in an abstinence dominated treatment system, as the case of Poland shows, see no chances for the implementation of DUCPs and identify both cultural and addiction-related barriers (i.e. the lack of acceptance for providing alcohol). At the same time, they recognise the potential of DUCPs in terms of the importance of harm reduction measures and pragmatism of a bottom up perspective.

Keywords: Poland, Harm reduction, Qualitative research, Wet places, Alcohol treatment system
Materiał i metody: Dwudziestu sześciu terapeutów zatrudnionych $\mathrm{w}$ polskim systemie alkoholowego lecznictwa ambulatoryjnego wzięło udział w czterech zogniskowanych wywiadach grupowych, które zostały nagrane na dyktafon, a następnie poddane transkrypcji dosłownej i analizie jakościowej przy wykorzystaniu programu do wspomaganej komputerowo jakościowej analizy danych (ATLAS.ti wersja 7.5.9).

Wyniki: Zidentyfikowano trzy typy przeszkód w implementacji programów redukcji szkód dla osób uzależnionych od alkoholu: (1) orientacja na abstynencję i związany z nią obraz uzależnienia; (2) poczucie nieadekwatności programów do postrzeganych cech, potrzeb i możliwości osób uzależnionych; (3) normy kulturowe i polski kontekst społeczno-historyczny.

Omówienie: Podawanie osobom uzależnionym substancji, od której są uzależnione, narusza tabu i jest najbardziej krytykowanym elementem programów, nawet jeśli idzie $\mathrm{w}$ parze $\mathrm{z}$ akceptowaną społecznie aktywnością, jaką jest podjęcie pracy i de facto redukcja wielu szkód społecznych wynikających z uzależnienia.

Wnioski: Przykład Polski pokazuje, że terapeuci będący częścią systemu lecznictwa zorientowanego na abstynencję nie dostrzegają możliwości rozszerzenia oferty o programy redukcji szkód, wskazując na szereg barier w ich implementacji. Jednocześnie osoby uczestniczące w badaniu dostrzegają potencjał, wagę i siłę tych programów w redukowaniu realnych problemów, których doświadczają zmarginalizowane społecznie osoby głęboko uzależnione od alkoholu.

Słowa kluczowe: Polska, programy redukcji szkód dla osób uzależnionych od alkoholu, badania jakościowe, system lecznictwa uzależnienia od alkoholu

\section{- INTRODUCTION}

By the end of the 1980s, a reorientation of alcohol policies from 'alcoholism' to 'alcohol-related problems' was observed, which led to a broadening of prevention programme strategies [1]. The focus shifted gradually from consumption-oriented control measures to alcohol-related social consequences such as accidents, suicides, violence and public order [2]. The recognition and mapping of alcohol-related harm [3] paved the way for the appli- cation of a harm-reduction approach to the area of alcohol problems [4-6].

Community action on alcohol [7], safer drinking places, warning labels and awareness campaigns [overview: 8] as well as brief interventions in generalist settings [e.g. 9, 10] are used as specific strategies to target non-treatment seeking population groups with only low levels of alcohol-related problems [11]. Heavy disadvantaged problem drinkers, unlikely to adopt total abstinence or harm-free drinking repre- 
sent the other target group of harm reduction programmes. Interventions include 'teachable moments' in trauma centres or emergency departments. Drinking under control programmes (DUCPs) represent a harm reduction strategy for people with severe alcohol dependence that are unwilling to pursue abstinence and are typically homeless so called street alcoholics' [12]. Different types of DUCPs include housing first programmes aiming at harm reduction by providing stable living conditions; wet houses with accommodation tolerating or managing alcohol consumption more systematically by 'providing beverage alcohol of known quality to programme participants at regular intervals to stabilise drinking patterns and to replace non-beverage alcohol which can be more hazardous' [13: 1]; wet drop-ins without accommodation, selling and/or tolerating alcohol brought to the meeting place and community action programmes using controlled alcohol access within, for example, work initiatives [14]. DUCPs in the Anglophone countries so far are mainly limited to the specific case of wet houses providing stable accommodation $[13,15]$.

McIntyre [16] provides a review of 40 (11 in detail) projects in Canada, the USA, Ireland and England and observes that 'a majority offer shortterm or emergency accommodation and/or despite exercising a very tolerant attitude to alcohol and drug use, typically stop short of allowing alcohol to be consumed on site' [16: 1]. Scarce evidence is available on resistance towards the implementation of DUCPs and more specifically barriers to include and systematically control alcohol access and consumption patterns.

The study presented here, explores and highlights the assessment of two types of DUCPs by outpatient treatment providers working in Polish treatment system. Drinking under control programmes case studies were selected from Switzerland and Netherlands, as those countries have developed treatment systems considered as traditionally 'experimental', pragmatic and open to harm reduction approach; the four-pronged national drug policy of Switzerland includes prevention, repression, treatment and harm reduction $[12,17,18]$. The confrontation of alcohol therapists from the abstinence-oriented Polish treatment system with alcohol harm-reduction programmes pursues the objective of identifying barriers of implantation and potential benefits and relative advantages of integrating DUCPs into the current treatment system.

\section{- Material and methods}

\section{Procedure}

In order to explore the perception of DUCPs among professionals working in outpatient alcohol treatment facilities, researchers needed to access the range of views of actors for whom the issue is potentially relevant. The focus group interview (FGI) method was chosen as best suited for the study objectives. The main reason to generate data with FGI is a chance to observe and analyse the whole interactive discussion, and arguments, which were prepared and voiced to present one's own views and defend one's own opinions in a group situation [19].

A semi-structured topical guideline was developed by the investigating researcher who introduced the group discussions with a presentation of two DUCPs (What comes to mind when you hear about that programme?), followed by additional probing questions about the benefits and risks of running programmes of this kind and perception of the chances of introducing DUCPs in Poland. That technique was used in order to generate new qualitative data as many of participants have never heard of the DUCP concept and gain a deeper understanding of perceptions and attitudes towards DUCPs among treatment providers. Two types of DUCPs were selected as a vignette for focus group discussions: firstly a wet drop-in tolerating alcohol brought to the meeting place ( $t$-alk Switzerland) and secondly a community action programme using controlled alcohol access as part of a work initiative (veeg Netherlands) [12]. These DUCPs cases were chosen to provide a complementary perspective to the prevailing concept of wet houses. Furthermore, the implementation of this type of DUCPs requires fewer resources than housing programmes and is therefore particularly relevant in times of financial cuts in the treatment system. The specific profiles of the two DUCPs introduced in the focus groups were as follows:

\section{Case I. T-alk Switzerland ${ }^{1}$}

This case started as a pilot project by the Department of Social Affairs of the city of Zürich in 2001 with the objective to get severely alcohol dependent men and women off the street and improve their social integration and health status [20]. The project

\footnotetext{
${ }^{1}$ https://www.youtube.com/watch?v=dFQRYhviLUI accessed 13 October 2016
} 
was permanently implemented in 2003 . The programme offer resembles drop-in programmes for drug users and includes work (cooking, recycling, auxiliary help for running the programme), leisure time activities and aid for survival (cheap meals, personal hygiene and clothing). Daily opening hours are from 10.15 to 17.30 . Clients are mostly male, with alcohol problems, unemployed and in the 45 to 65 years age group. Most of them are not homeless. Alcohol management has remained an integral part of the overall concept as visitors can bring their own alcohol (wine or beer, no limit of quantity) and consume it on-site while observing rules like no violence, no weapons, no illicit drugs, no medication and no hard liquor. Breaking the rules leads to temporary exclusion or denial of access. This measure (one to three days access denied) had to be taken in one to two cases per week and longer exclusions ( 2 weeks to 6 months) occurred in three to five cases in 2013. The programme has about 70 visitors per day, which points to a relatively high compliance. In addition, participation in the open outpatient controlled drinking group is offered to visitors [12].

\section{Case II. The 'veeg' project Netherlands ${ }^{2}$}

The 'veeg' project/alcohol consumption room (Amsterdam, Netherlands). Following complaints about nuisance (fights, noise, littering) caused by chronic alcohol addicts in Amsterdam's Oosterpark, the Rainbow Foundation launched a participatory project in 2012, which in 2014 was adopted in additional city districts of Amsterdam. It is subsidised by the municipal welfare office based on the $1 €$ job promotion scheme. The objective was to keep street alcohol addicts occupied, so they would no longer cause a nuisance, to influence their health status and quality of life positively and to negotiate their alcohol intake. Programme participants work three days a week cleaning streets in teams of $4-5$, starting at 8.00 a.m. with breakfast, coffee and two cans of beer. When participants arrive already drunk in the morning, the issue is discussed in order to achieve gradual reduction of early morning consumption, which enables them to work. After two hours of work they return and can drink another can of beer and later have hot lunch with two more cans of beer. They return

\footnotetext{
${ }^{2}$ https://www.theguardian.com/world/2014/jan/16/dutchscheme-reintegrate-alcoholics-beer-amsterdam accessed 13 October 2016
}

at 14.00 and after cigarettes and having another beer, work for another two hours. After that they receive $€ 10$ and another can of beer [12].

\section{Participants}

The 26 alcohol addiction counsellors working in outpatient facilities in different parts of Poland were participants of four focus groups conducted from June to August 2015. We decided to include only outpatient treatment facilities as they are representing $66 \%$ of all Polish alcohol treatment facilities [21]. To ensure rich and differentiated data, therapeutic teams from three different cities were chosen and invited to participate in the FGI (city 1 with population below 200000 , city 2 with population below 600 000, city 3 - Warsaw with 1700000 inhabitants). Moreover the additional, fourth, FGI was composed of eight therapists with experience of therapy towards moderation of alcohol use working in different facilities in different parts of Poland.

\section{Ethics}

The study presented here is not a medical experiment and does not involve patients. Each participating therapeutic team received an invitation and written information describing the study aim, funding sources, possible benefits and risks for the participants. All participants were assured that their anonymity would be protected and that participation in the study is voluntary.

\section{Data analysis}

All FGI were audio-recorded and transcribed verbatim following participants' verbal consent. Focus group interviews lasted on average $30 \mathrm{~min}$ utes. Data were collected, coded and analysed using ATLAS.ti software (version 7.5.9). The transcripts were coded 'sentence by sentence' in order to capture the meaning of data, and linked with the more general, thematic categories presented below. Female participants (marked as ' $F$ ') and male participants (marked as ' $M$ ') were numbered from 1 to 6 (by order of appearance) during the FGI (marked from 1 to 4 ) to show interaction patterns and flow of conversation during the group discussions.

\section{- Results}

In total 26 therapists from 13 different therapeutic teams participated in focus group inter- 
views - 17 women and 9 men working in outpatient facilities in different parts of Poland (broken down by groups: $1^{\text {st }}$ FGI: two women $[\mathrm{F}]$ and four men $[M] ; 2^{\text {nd }}$ FGI: six F and three M; $3^{\text {rd }}$ FGI: three F; $4^{\text {th }}$ FGI: six $\mathrm{F}$ and two $\mathrm{M}$ ).

Despite some FGI participants liking the concept and others strongly opposing it, all participants agreed that the introduction of DUCPs in Poland would be impossible at the present moment.

\section{FGI-3}

F2: I don't have the feeling it is possible in Poland. It is too early for it. It would be seen as encouraging drinking not the other way round. That it is about moderation of drinking, teaching how to drink in good, safe, clean conditions. The social perception of a programme like this would be very negative.

Three major types reasons were expressed about the barriers to the introduction of DUCPs in Poland: cultural differences, the prevailing drug-free therapeutic ideology and specific characteristics/ profiles of potential clients of DUCPs.

\section{Cultural differences}

Participants pointed to differences related to Polish history and culture that may be reasons for not introducing DUCPs, most prominently the infamous history of using alcohol to control society and the top-down model of administration.

\section{FGI-1}

M1: It is good such programmes are created, and that it is a bottom-up initiative. Most things in Poland are created top-down, and are totally disconnected from reality. But in Poland alcohol was historically used as payment for work.

F1: Unfortunately.

M1: Feels like going backwards in history to serfdom...

M2: Yes, cause idea is still the same: to control people. The same was the case in communist times, you would get ration coupons for addictive goods in order to control people. (...) Western countries might have different experiences, it maybe makes it easier to introduce such programmes. In Poland we still might need a few generations to pass, we might need education, we might need an experience of living in different societal realities.

F1: I also think that programme has to be culturally adjusted to the country. Just copying and past- ing from other realities is a mistake. Programmes need to be rooted in the reality of the country.

Participants also believe that another barrier is related to social norms and the perception of addicts and addiction.

\section{FGI-4}

F2: Totally crazy [concept].

F4: It is a different culture. And this is why it is functioning there. Honestly, I can't imagine that in Polish reality. There would be no obeying rules about violence and binging.

M1: How to even determine when a person is drunk and when not?

F4: I am utterly shocked by it ['veeg']. They are given lots of alcohol, they are taught that work under the influence is not a problem. (...) It sends the wrong message. What if he has to climb a ladder to the fourth floor, will we also allow it under the influence? (...) Where are the limits we can't cross?

F1: Some social norms.

F4: Would you like to live in a society where it is allowed? Not me!.

\section{Drug-free perspective}

The concept of DUCPs was also quite shocking for therapists who represent the abstinence-only perspective, and are used to a directive and paternalistic patient-therapist relationship.

\section{FGI-3}

F3: I don't know. It scares me. It touches on the diffcult subject of balance between acceptance and change. To what extent do we accept what our client does and to what extent do we want to change what is dysfunctional?

F1: It makes sense. But it is impossible in Poland.

F3: I think so too... because of the Polish mentality, stereotypes, thinking «what our taxes are used for».

F2: Yes, that we create places to drink.

F1: That we accept drinking. The media would make a lot of noise.

F3: But with drugs... harm reduction succeeded.

F1: I am unable to imagine such a programme. (...) It could be done, but it would require that the staff members of those programmes share a very positive attitude, value acceptance and respect for the other person and his/her choices.

\section{FGI-1}

F4: What is most shocking is allowing them to drink. M2: Supporting addiction. 
F4: Yes. And providing them with alcohol.

M2: One programme dispenses, the other allows.

F1: That is what shocks us.

\section{FGI-4}

F5: I would not want to work in a programme like that with a client who is using alcohol.

F4: His abstinence is something he gives from himself. (...) This programme reduces harm for the society but not for the person. (...) They are removed, so we don't see them and we don't see what is happening there and we call it harm reduction. But it is comfort of our life that is increased.

Characteristics of drinking under control programmes potential clients

Therapists claim that on the one hand their typical client is a target of structural stigma and there is no will to improve his/her life situation, and on the other they themselves perceive their clients as difficult to control and inclined to disobey the rules.

\section{FGI-1}

M1: Alcohol addict, drug addict... those labels are attached for the whole life. Stigma attached to addiction is very strong and difficult to change, so giving to those people something more than to a normal, healthy person will meet with very little acceptance. (...) There is no will to increase their comfort, to change anything, because they are perceived negatively and marginalised.

\section{FGI-2}

F2: Knowing our patients, they would take those six cans of beer and sell them to buy strong alcohol.

F4: They would find a way for sure.

F5: Still, they would have to do a few hours of work to get the beer, right?

F2: Absolutely. We say in Poland that forced labour is wrong, but here we have the programme, which encourages work.

F5: 10 EURO per day it is not that much, right?

F2: There is lots of work those people could do if city councils organised it.

Regardless of the general pessimism when it comes to the implementation of DUCPs within the present Polish alcohol treatment system, potential benefits of DUCPs also emerged in group discussions.

\section{Potential benefits}

Some FGI participants have found DUCPs concept inspiring and thought provoking, therefore part of the group discussions was focused on benefits of such programmes, which were in fact related to general features of the harm-reduction approach. More specifically, DUCPs were perceived as pragmatic, realistic and safe, restoring dignity, reaching out for hidden populations and supporting change of most destructive drinking patterns.

\section{FGI-2 (harm-reduction)}

M2: I imagine the group of clients who are hitting rock bottom, having a crisis in their lives. If they go to a place like this, where their dignity is respected, they have an immediate chance of getting help. Somebody can talk to them and encourage them to start treatment.

F5: No more a rolling stone - they have a job and streets are clean.

F4: It is confusing and shocking... on the other hand, when I think of some of my patients, not paying alimonies, living on the street, being taken to sobering-up stations, or night shelters... they are drinking anyway...

M1: Drinking happens in night shelters anyway whether it is allowed or not. We all know it, but we don't accept it. Maybe it is better to simply accept.

FGI-1 (less destructive drinking pattern)

F1: I am thinking of altering the way the client uses the substance, of taming it by changing the very strong alcohol for the less strong one, and drinking it in the atmosphere of conversation...

\section{FGI-3 (safer)}

F3: The idea of creating nice, safe places, which are clean, not in front of the local store, but where one can sit, drink and talk... it is better they drank that way than hiding in the bushes.

\section{Comparison of the DUCPs cases}

As we selected two DUCPs from two different countries, following different objectives, part of the group discussions was focused on the comparison between $t$-alk and veeg. Consequently programme preferences and the assessment of specific features emerged: therapists supported the idea of structuring the day and providing work, meals, 
and social interaction though the idea of providing alcohol was considered very controversial.

\section{FGI-1}

F2: I prefer the «t-alk» programme than «veeg». I am against the idea of using alcohol as payment. If they want to use alcohol they should buy it themselves. Paying for work with alcohol makes me feel uneasy. On the other hand... as you said, they would drink anyway, and have a chance to do something, have some responsibilities, maybe it might stop them from stealing to get money for beer. So it makes sense when it comes to harm reduction, not only medical harm, but also social harm.

\section{FGI-2}

F2: I would be willing to accept the fact they are given money. What they do with it is their business. Maybe they will spend the money on alcohol, maybe on food.

M1: That is easier to accept.

F2: Yes, because it is their choice.

\section{FGI-3}

F3: In «veeg», at least they are trying to teach some social functioning. It is an important difference.

F2: They work, and they are paid for their work with alcohol.

F1: And this is something I can't accept.

F3: If you gave them money, they would buy it [alcohol] anyway...

F1: True. Maybe some cheap wine, or ...

F1: Or any other type of alcohol.

F2: I also accept «veeg» more. There is work, and the other one ['t-alk'] is just, I imagine, just sitting at the table and drinking. At «beer for work» there are certain quantities at certain time. They are not sitting and getting drunk [as in 't-alk'].

F3: If I had a person who has lots of interpersonal problems, I would recommend «t-alk».

F1: [Both programmes have] different objectives. I also think that «veeg» is more structured, certain work, at a certain time and... alcohol. But I also think that giving them alcohol... it would be impossible to accept in Poland.

F3: I remember a study with giving cocaine to rats in good conditions and with other stimuli and rats stopped using it. I think that «t-alk» is more stimulating, gives more reason to stop drinking. «Veeg» is just work, and... beer after work... but it has more structure. Both programmes have pros and cons.

\section{- Discussion}

The article presents the results of a study that focuses on the perception of two selected DUCPs in the Netherlands and Switzerland by outpatient treatment providers working in the Polish abstinence-focused alcohol treatment system. Drinking under control programmes cases were selected from Switzerland ( $t$-alk) and Netherlands (veeg) as those countries represent treatment systems considered 'experimental', pragmatic and open to the harm reduction approach [12].

A wide consensus emerged from the FGI participants that the DUCPs implementation in Poland would not be possible. To begin with, wider social conditions potentially hamper chances for DUCPs implementation as participants see it. Orientations towards abstinence and related images of addictions are seen in conflict with the idea of DUCPs.

In this context it can be noted, that the media and the general public response in terms of addiction-related stigma and stereotypes are critical to the introduction of DUCPs. The programmes met with much controversy in public debate, particularly in their starting phase, including attitudes that DUCPs' clients should not be rewarded for their deviant behaviour, that the provision of alcohol to addicted individuals worsens their condition, that unrestricted drinking scenarios cannot be eliminated and that DUCPs lead to pull effects and to trouble in the neighbourhood.

More specifically, socio-cultural norms related to historical features and collective memories in Poland as a post-communist country were discussed. A leitmotif emerging here is the role of providing or tolerating alcohol in the DUCPs presented. Both in the Netherlands and in Switzerland this topic has been seen as controversial, similarly to the debates on drug substitution and heroin-prescription programmes [18]. Focus group interview participants referred to the role of alcohol in Polish society. More specifically they discussed the process of using or facilitating access to alcohol as a means to achieving social and political control and pursue top down policies (back to serfdom). Additionally, it was assumed that more general values and beliefs in Poland about 'following the rules' and 'being disciplined' are not compatible with the requirements of the DUCPs.

These societal images of addiction were partially mirrored in the assessment of specific pro- 
gramme characteristics by the clinicians. First of all, removing street alcoholics from the public eye is furthermore seen as a benefit for society but not the person. As potential benefits and ways to relate to the public discussion, clinicians identified the provision of alcohol as breaking a taboo lying at the centre of critique, even when linked with work like its important social value, and regardless of the harm reduction perspective and the outcomes of DUCPs, which were only marginally referred to. At the same time both DUCPs were perceived as quite balanced in their advantages and disadvantages: veeg in its emphasis on work and good structure yet at the same time providing alcohol, and $t$-alk, which tolerated consumption and allowed for more social exchange while being less structured and challenging. Furthermore, suggestions for matching specific target groups with the type of DUCPs were forwarded and the strong participatory character of both programmes was seen as a valuable benefit. Both DUCPs were perceived as pragmatic, realistic and safe, restoring dignity, reaching out for hidden populations, and supporting the change of the most destructive drinking patterns. Referring to the organisational level and programme structures, FGI participants pointed out the difficulties of matching client profiles with programme characteristics. The perception of clients among treatment providers is characterised by mistrust and suspicion that DUCPs would be misused.

To put these findings into context, it must be kept in mind that the attitudes and beliefs of treatment providers represent only one important element promoting or impeding the integration of DUCPs into the response to substance-use disorders and the treatment system.

Programme funders expect evidence before continuing subsidies and implementing DUCPs into regular provider structure. However, this evidence is scarce and evaluation efforts are mostly limited to self-evaluations. This is because of programme providers' lack of resources to conduct 'academic outcome evaluation research' along with a seeming lack of research community interest in this topic [with recent exception: 13]. Accordingly, the review by Ritter and Cameron [22] shows that the majority of the literature is mainly concerned with illicit drugs. This has methodological and conceptual reasons. While DUCPs providers consider a broad range of success indicators, evaluation research in this area is focused mainly on changes in alcohol consumption. This has proved to be a 'dead end street' as the Cochran review of DUCPs has shown in its assessment of the effectiveness of DUCPs treatment regimens $[17,18]$.

It is a limitation of this study that the sample represented in the four focus groups is not representative of the whole Polish population of alcohol addiction therapists, and caution should be exercised in generalising from the findings. However, the diversity of the sample (26 participants from 13 different therapeutic teams from different parts of Poland) allowed for a broad scope of perspectives. The focus on participatory community action and a wet dropin excluded other types of DUCPs from discussion.

To conclude, outcome criteria and success of DUCPs are in fact contingent upon public preferences and that of treatment providers and the research community, which could assume a constructive role as a mediator to facilitate the acceptance of DUCPs. Treatment policies are based on the changing definition of national priorities on outcomes [23]. Uchtenhagen claims that the 'pyramid of treatment goals is no longer topped by abstinence or reduction of use. A subjectively defined quality of life... makes a good replacement at the top' [23:491].

\section{Conflict of interest/Konflikt interesów}

None declared./Nie występuje.

\section{Financial support/Finansowanie}

The NCT-PL study presented in the article was funded by the State Agency for the Prevention of Alcohol-Related Problems (PARPA), grant agreement no. 502-002-14022./Badanie zostało sfinansowane przez Państwową Agencję Rozwiązywania Problemów Alkoholowych, nr grantu 502-002-14022. 
Drinking under control programmes: perception of alcohol-related harm reduction measures in Poland. Results of a qualitative study among outpatient alcohol treatment providers

Percepcja programów redukcji szkód skierowanych do osób uzależnionych od alkoholu. Wyniki badania jakościowego wśród

\section{Ethics/Etyka}

The work described in this article has been carried out in accordance with the Code of Ethics of the World Medical Association (Declaration of Helsinki) on medical research involving human subjects, EU Directive (210/63/EU) on protection of animals used for scientific purposes, Uniform Requirements for manuscripts submitted to biomedical journals and the ethical principles defined in the Farmington Consensus of 1997.

Treści przedstawione w pracy są zgodne z zasadami Deklaracji Helsińskiej odnoszącymi się do badań z udziałem ludzi, dyrektywami UE dotyczącymi ochrony zwierząt używanych do celów naukowych, ujednoliconymi wymaganiami dla czasopism biomedycznych oraz z zasadami etycznymi określonymi w Porozumieniu z Farmington w 1997 r.

\section{References/Piśmiennictwo}

1. Room R. Recent research on the effects of alcohol policy changes. JPrim Prev 1990; 11 (1): 83-94.

2. Klingemann H, Gmel G. Mapping the Social Consequences of Alcohol Consumption. Dordrecht: Kluwer Academic Publishers; 2001.

3. Witkiewitz K, Marlatt GA. Overview of harm reduction treatments for alcohol problems. Int J Drug Policy 2006; 17 (4): 285-94.

4. Blume AW. Seeking the middle way: G. Alan Marlatt and harm reduction. Addict Res Theory 2012; 20 (3): 218-26.

5. Logan DE, Marlatt GA. Harm reduction therapy: a practice-friendly review of research. J Clin Psychol 2010; 66 (2): 201-14.

6. Marlatt GA, Witkiewitz K. Update on harm-reduction policy and intervention research. Annu Rev Clin Psychol 2010; 6: 591-606.

7. Shakeshaft A, Doran C, Petrie D, Breen C, Havard A, Abudeen A et al. The effectiveness of community action in reducing risky alcohol consumption and harm: a cluster randomised controlled trial. PLoS Med 2014; 11 (3): e1001617-e1001617.

8. Plant M. Harm minimization. Mapping the social consequences of alcohol consumption. In: Klingemann H, Gmel G (eds.). Mapping the Social Consequences of Alcohol Consumption. Dordrecht: Kluwer Academic Publishers; 2001, 145-60.

9. Kypri K, Vater T, Bowe SJ, Saunders JB, Cunningham JA, Horton NJ et al. Web-based alcohol screening and brief intervention for university students a randomized trial. JAMA 2014; 311 (12): 1218-24.

10. Patton R, Deluca P, Kaner E, Newbury-Birch D, Phillips T, Drummond C. Alcohol screening and brief intervention for adolescents: the how, what and where of reducing alcohol consumption and related harm among young people. Alcohol Alcohol 2014; 49 (2): $207-12$.

11. Heather N. Controlled drinking, harm reduction and their roles in the response to alcohol-related problems. Addict Res Theory 2006; 14: 7-18.

12. Klingemann H, Klingemann JI. Unknown and under-researched: The anatomy of drinking under control programs. SUCHT 2017; 63 (5): 277-88.

13. Vallance K, Stockwell T, Pauly B, Chow C, Gray E, Krysowaty B et al. Do managed alcohol programs change patterns of alcohol consumption and reduce related harm? A pilot study. Harm Reduct J 2016; 13: 13.

14. Muckle W, Muckle J, Welch V, Tugwell P. Managed alcohol as a harm reduction intervention for alcohol addiction in populations at high risk for substance abuse. Cochrane Database Syst Rev 2012; 12: CD006747.

15. Pauly B, Gray E, Perkin K, Chow C, Vallance K, Krysowaty B et al. Finding safety: a pilot study of managed alcohol program participants' perceptions of housing and quality of life. Harm Reduct J 2016; 13: 15.

16. McIntyre S. Wet Housing - an accommodation option for people who have experienced chronic homelessness and long-term alcohol dependence. Wellington: Downtown Community Ministry; 2009. 
17. Derks JT, Hoekstra MJ, Kaplan CD. Integrating Cure, Care and Control: The Drug Treatment System in the Netherlands. In: Klingemann H, Hunt G (eds.). Drug Treatment Systems in an International Perspective. Thousand Oaks, London, New Delhi: SAGE; 1998, p. 81-93.

18. Klingemann H. Harm Reduction and Abstinence: Swiss Drug Policy at a Time of Transition. In: Klingemann H, Hunt G (eds.). Drug Treatment Systems in an International Perspective. Thousand Oaks, London, New Delhi: SAGE; 1998, p. 94-111.

19. Barbour R. Doing Focus Groups. London: SAGE Publications; 2007.

20. Grichting E, Frei A, Rehm J. Evaluation des Treffpunkts für Alkoholikerinnen und Alkoholiker t-alk. Zürich: Addiction Research Institute; 2002.

21. Klingemann J. Acceptance of reduced-risk drinking as a therapeutic goal within the Polish alcohol treatment system. Alcohol Alcohol 2016; 51: 436-41.

22. Ritter A, Cameron J. A review of the efficacy and effectiveness of harm reduction strategies for alcohol, tobacco and illicit drugs. Drug Alcohol Rev 2006; 25 (6): 611-24.

23. Uchtenhagen A. Commentary on Metrebian et al. What is addiction treatment research about? Some comments on the secondary outcomes of the Randomized Injectable Opioid Treatment Trial. Addiction 2015; 110 (3): 491-3. 